\title{
An unusual cyst nematode from New Zealand, Paradolichodera tenuissima gen. n., sp. n. (Tylenchida: Heteroderidae)
}

\author{
Dieter STURhan $^{1, *}$, Wim M. Wouts ${ }^{2}$ and Sergei A. Subbotin ${ }^{3,4}$ \\ ${ }^{1}$ Arnethstr. 13D, 48159 Münster, Germany; formerly Biologische Bundesanstalt für Land-und Forstwirtschaft, \\ Institut für Nematologie und Wirbeltierkunde, 48161 Münster, Germany \\ ${ }^{2}$ Chessell Drive, Duncraig 6023, Perth, Western Australia; formerly Landcare Research, Auckland, New Zealand \\ ${ }^{3}$ Plant Pest Diagnostic Center, California Department of Food and Agriculture, 3294 Meadowview Road, \\ Sacramento, CA 95832-1448, USA \\ ${ }^{4}$ Department of Nematology, University of California, Riverside, CA 92531, USA
}

Received: 27 November 2006; revised: 5 April 2007

Accepted for publication: 5 April 2007

\begin{abstract}
Summary - A new genus, Paradolichodera gen. n., is proposed for a heteroderid species parasitising the rush Eleocharis gracilis on the banks of a lagoon near Christchurch, New Zealand. The slender body of the second-stage juveniles $(\mathrm{a}=61-79)$ makes the type species, $P$. tenuissima sp. n., unique among known Heteroderidae species. The females weakly tan after death and retain eggs. The cysts are elongate-ovoid with rounded posterior end, a circumfenestral vulva area in terminal position, an indistinct anus and a cuticle with faint striation anteriorly and punctations posteriorly. The male body is not twisted, a cloacal tube is present and phasmids are lacking. Morphologically, the new genus is closest to Dolichodera in the subfamily Punctoderinae. A phylogenetic analysis of the ITS1-rRNA sequence of P. tenuissima sp. n. shows a close relationship to Punctodera and Globodera.
\end{abstract}

Keywords - Cyperaceae, description, Eleocharis gracilis, ITS-rRNA, morphology, morphometrics, new genus, new species, Punctoderinae, phylogeny.

In a soil sample collected by the first author at the end of November 2000 from the rhizosphere of various plants along a lagoon south of Christchurch, New Zealand, a few extremely slender tylenchid juveniles, resembling at low magnification members of the Ecphyadophoridae, were identified as a new species of the family Heteroderidae. Subsequent sampling of rush species at the lagoon yielded more juveniles and a single cyst from Eleocharis gracilis R. Br. Further samples from this tentative host, taken later the same season, yielded sufficient cysts, females, males and juveniles for a description of the species.

In cyst and female characteristics the new species most closely resembles Dolichodera fluvialis Mulvey \& Ebsary, 1980, the only species representing the genus Dolichodera Mulvey \& Ebsary, 1980, which was described without males and is known only from an aquatic habitat in Canada. The slender second-stage juveniles of the new species from New Zealand are, however, remarkably different from those of $D$. fluvialis and from all other known heteroderid species. Their unique characteristics and certain features of the cyst are considered sufficient to justify the proposal of this new species as the type of the new genus Paradolichodera.

\section{Materials and methods}

\section{MORPHOLOGICAL STUDY}

The nematodes were extracted from soil and root samples by the sieving-decanting method and the centrifugation-flotation technique. They were killed and fixed with hot $4 \%$ formalin and transferred to pure glycerin by a slow evaporation method. Nematode specimens on permanent glycerin mounts were used for the light microscopical studies and for taking photomicrographs. For observation in a Philips 505 SEM, selected specimens fixed in $4 \%$ formalin were cleansed ultrasonically, passed through a graded ethanol series (10-30-50-70-90-100\%), critical point dried, mounted on a stub and coated with gold in an Emscope SP2000 sputter cryo unit.

\footnotetext{
* Corresponding author, e-mail: D.Sturhan@bba.de
} 


\section{DNA EXTRACTION, PCR AMPLIFICATION, SEQUENCING AND PHYLOGENETIC ANALYSIS}

DNA was extracted from several juveniles using proteinase K. Detailed protocols for DNA extraction, PCR, cloning and sequencing are described by Tanha Maafi et al. (2003). The forward TW81 (5'-GTTTCCGTAGGT GAACCTGC-3') and reverse 5.8SM5 (5'-GGCGCAATG TGCATTCGA-3') primers were used for amplification and sequencing of the ITS1 region of rRNA (Zheng et $a l ., 2000)$. The sequence of the ITS1-rRNA for P. tenuissima gen. n., sp. n. is deposited in GenBank under accession number DQ847121. The ITS1-rRNA sequence of $P$. tenuissima gen. n., sp. n. was aligned with published sequences of 11 species of the subfamily Punctoderinae (Ferris et al., 1999, 2004; Subbotin et al., 2000, 2001; Sabo et al., 2002; Tanha Maafi et al., 2003) and two species of non-cyst forming heteroderids as outgroup taxa, viz., Cryphodera brinkmani Karssen \& van Aelst, 1999 and Meloidodera alni Turkina \& Chizhov, 1986 (Subbotin et al., 2001), using ClustalX 1.83 with default parameters (Thompson et al., 1997). Sequence alignment was analysed using maximum parsimony (MP) performed with PAUP* 4b10 (Swofford, 2003). Heuristic search setting was used with ten replicates of random taxon addition, tree bisection-reconnection branch swapping to seek the most parsimonious trees. Gaps were treated as missing data. Robustness of the clades was assessed using bootstrap analysis yielding a bootstrap percentage (BP) for each node estimated from 1000 replicates.

\section{Paradolichodera* ${ }^{*}$ gen. $\mathbf{n}$.}

\section{DiAgNOSIS}

Heteroderidae, subfamily Punctoderinae.

\section{Mature female and cyst}

Elongate-ovoid, with rounded posterior end. Cuticle transparent, with faint transverse striation on anterior part of body and distinct punctation, mostly with faint irregular ridges superimposed, on posterior part of body, turning yellowish to light brown on death; cover resembling a subcrystalline layer present. Eggs retained in body; egg sac not observed. Labial disc squarish. Stylet well

\footnotetext{
* Generic epithet derived from the Greek para (= beside, near), and Dolichodera. It is so named to indicate the close relationship of this new genus to Dolichodera.
}

developed. Vulva terminal or subterminal; vulva slit short, circumfenestrate. Anus lacking fenestration.

Male

Body not twisted, lateral field with four incisures. Cloacal tube present; spicules rounded at tip. Phasmids lacking.

\section{Second-stage juvenile}

Body long and extremely slender for family; lateral fields indistinct. Stylet short $(<20 \mu \mathrm{m})$. Dorsal gland orifice located more than half stylet length posterior to stylet base; pharyngeal glands long, filling body cavity. Tail long, slender; phasmids punctiform.

\section{TYPE AND ONLY SPECIES}

Paradolichodera tenuissima gen. n., sp. n.

\section{Hosts}

The rush Eleocharis gracilis $\mathrm{R}$. Br. is the only known host of Paradolichodera tenuissima gen. n., sp. n., the type and only species of the genus. Other members of the family Cyperaceae or related monocotyledonous plants may be putative hosts.

\section{DIAGNOSIS AND RELATIONSHIPS}

Morphological characters, such as transformation of females into cysts and fenestration around the vulva, place Paradolichodera gen. n. in the subfamily Punctoderinae Krall \& Krall, 1978. The subfamily includes the genera Cactodera Krall \& Krall, 1978, Dolichodera Mulvey \& Ebsary, 1978, Globodera Skarbilovich, 1959, Punctodera Mulvey \& Stone, 1976 and Betulodera Sturhan, 2002. Molecular studies by Subbotin et al. (2002), in which Paradolichodera gen. n. was tentatively identified as 'Dolichodera sp.', support placement in Punctoderinae, showing a sister relationship between Paradolichodera gen. n. and the genus Punctodera. Recent more detailed analyses of the D2-D3 expansion segments of the 28S rDNA gene confirmed the earlier results (Subbotin et al., 2006). Analysis of the ITS1-rDNA sequences showed that Paradolichodera gen. n. shares a unique clade with Punctodera and Globodera (this paper). Material of $D$. fluvialis was not available for these molecular studies.

Paradolichodera gen. n. differs from Cactodera by the rounded posterior end of the cysts ( $v s$ protruding vulval area), from Punctodera by the absence of an 
anal fenestration, and from Globodera and Betulodera by the absence of a distinct lace- or network-like pattern in the cyst cuticle. In cyst characters Paradolichodera gen. n. closely resembles Dolichodera, particularly in the thin and irregularly striated cuticle, but bullae are absent in Paradolichodera gen. n. vs present in Dolichodera. Second-stage juveniles of the single species known in both genera can be distinguished by many morphological characters (e.g., slenderness of the body, distance of the dorsal gland orifice from the stylet knobs and distance of the phasmids from the anus).

\section{Paradolichodera tenuissima* gen. n., sp. n. = Dolichodera sp. apud Subbotin et al., 2002}

\section{(Figs 1-4)}

\section{MeAsurements}

See Tables 1 and 2.

\section{DESCRIPTION}

\section{Female}

Body elongate to ovoid, posterior end rounded or occasionally weakly conoid. Anterior end tapering and mostly of irregular shape. Specimens often becoming creamy or yellowish during development. Layer of unknown origin (= subcrystalline layer?) often covering entire body. $\mathrm{Cu}-$ ticle with fine transverse striation, particularly on anterior part of body. Striae, towards posterior end, dissolved into rows of punctations with indistinct irregular longitudinal ridges superimposed. Labial disc squarish, off set, ca $5 \mu \mathrm{m}$ wide. Stylet generally slightly curved ventrally; knobs rounded and slightly directed posteriad; stylet base 5-6 $\mu \mathrm{m}$ wide. Dorsal gland orifice $10-12 \mu \mathrm{m}$ posterior to stylet base. Median bulb of pharynx globular, 15-29 $\mu \mathrm{m}$ diam. with 10-11 $\mu \mathrm{m}$ long valves. Vulva and anus terminal or subterminal, not protruding. Vulval slit 4-6 $\mu \mathrm{m}$ long; vulva-anus distance 18-36 $\mu \mathrm{m}$.

\section{Cyst}

Elongate-ovoid, with rounded posterior end, yellowish to light brown, filled with eggs or hatched juveniles easily visible through cuticle; neck narrow and mostly straight, off set. Cysts often covered with irregularly developed,

\footnotetext{
* Specific epithet derived from the Latin tenuissima $=$ very thin, and referring to the extremely slender form of the second-stage juveniles.
}

heavy 'subcrystalline' layer. No egg sac observed. Vulva and anus terminal or subterminal, not projecting. Vulval area circumfenestrate, fenestra $15-26 \mu \mathrm{m}$ in diam., bullae and underbridge lacking. Anus small, indistinct, without particular cuticle structures around it, $12-30 \mu \mathrm{m}$ dorsal to vulval fenestra margin. Cuticle finely striated in anterior part of body, approximately from mid-body striae gradually transforming into rows of punctations, heaviest and most irregular at posterior end, occasionally where they may be covered with irregular, faint, longitudinal ridges or reticulate structures. Cuticle 5-12 $\mu \mathrm{m}$ thick at mid-body.

\section{Male}

Body almost straight to C-shaped, posterior part not twisted about its longitudinal axis. Cuticle annules 1.5-2.0 $\mu \mathrm{m}$ wide at mid-body. Lateral field with four faint, equally spaced lines reducing towards anterior and posterior ends of body to irregular central lines or no line; outer ridges of lateral field mostly areolated. Deirids, postdeirids and phasmids lacking. Lip region rounded, flattened slightly anteriorly, set off from body, 10-11 $\mu \mathrm{m}$ diam., 5-6 $\mu \mathrm{m}$ high, with 6-8 annules and faint oval labial disc. Cephalic framework heavily sclerotised. Anterior cephalids located 2-3 annules and posterior cephalids 10-11 annules posterior to lip region. Stylet with conus shorter than cylindrical part including knobs; knobs rounded with flat or slightly posteriorly sloping anterior faces, generally well separated, forming a $6 \mu \mathrm{m}$ wide and 2.5 $\mu \mathrm{m}$ high cavity at stylet base. Median pharyngeal bulb elongate-oval, occupying less than half body diam.; valve plates well developed, $6 \mu \mathrm{m}$ long. Pharyngo-intestinal valve indistinct. Dorsal pharyngeal gland lobe generally wide, occasionally filling body cavity; subventral gland lobes slender, attached to ventral side of body cavity. Hemizonid $c a$ two cuticle annules long, $c a$ two body diam. from level of centre of median bulb. Excretorysecretory pore 6-12 $\mu \mathrm{m}$ posterior to hemizonid, 1.0$1.5 \mu \mathrm{m}$ wide. Testis well developed, occupying 38-70\% of body length. Spicules slightly arcuate with rounded tip, proximal part somewhat off set; gubernaculum almost straight, 9-12 $\mu \mathrm{m}$ long; wide, refractile cloacal tube present. Tail varying from almost hemispherical to bluntly conoid, 4-10 $\mu \mathrm{m}$ long, often with irregular terminal process.

\section{Second-stage juvenile}

Body very slender, mostly straight. Cuticle finely annulated; annules less than $1 \mu \mathrm{m}$ wide. Lateral field indistinct, visible only with SEM as irregular interruptions of cuticle annulation. Lip region off set, flatly rounded, 5.4-6.0 $\mu \mathrm{m}$ 


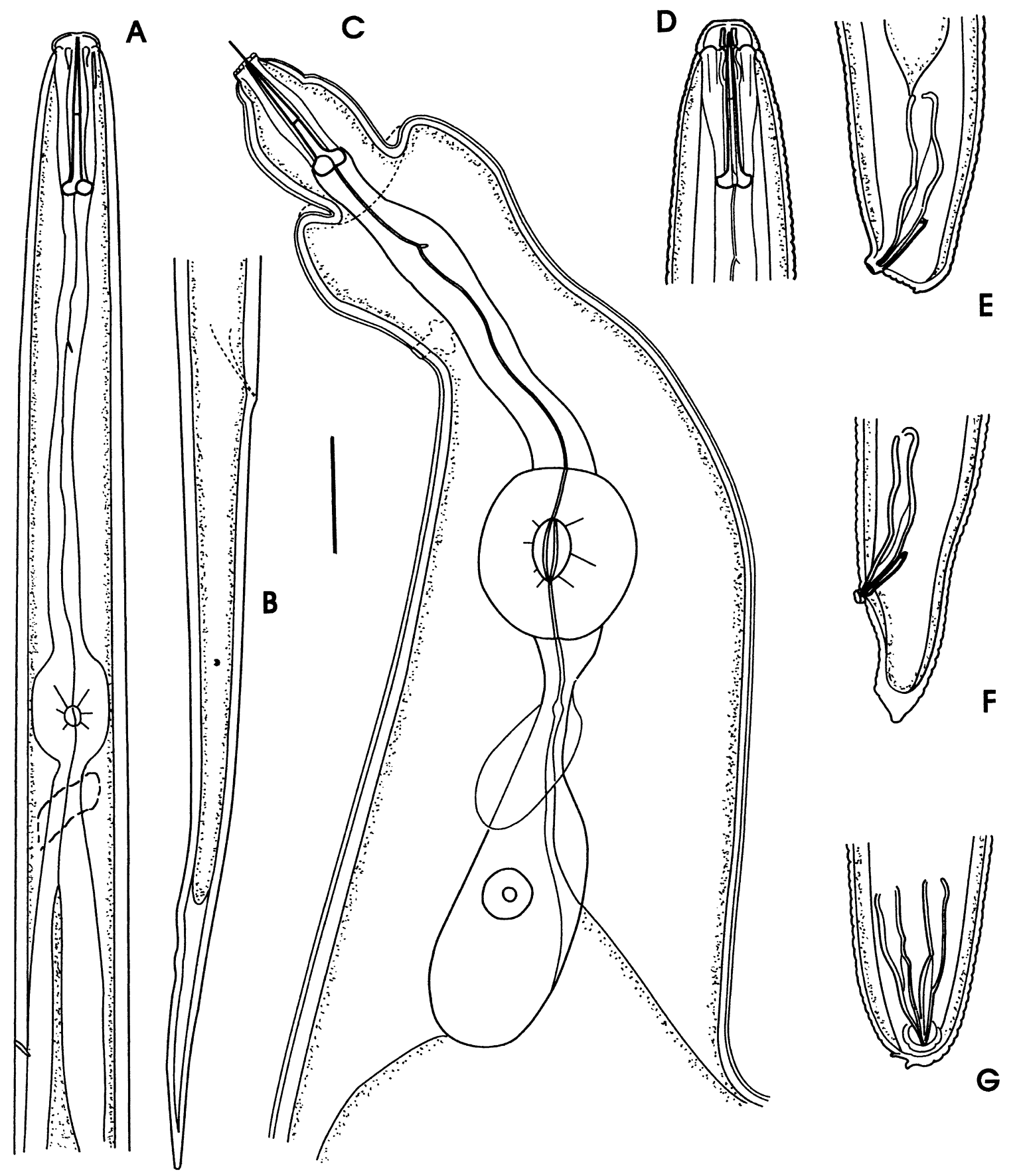

Fig. 1. Paradolichodera tenuissima gen. n., sp. n. A: Anterior end of second-stage juvenile; B: Tail of second-stage juvenile; C: Pharyngeal region of female; D: Head of male; E, F: Posterior end of male, lateral; G: Posterior end of male, dorso-ventral. (Scale bar: $A, B=15 \mu m ; C-G=20 \mu m$.)

Fig. 2. Paradolichodera tenuissima gen. n., sp. n. LM micrographs. A: Second-stage juveniles, entire body; B: Second-stage juveniles, anterior end; $C$ : Second-stage juvenile, posterior end; D: Male, anterior end; E, F: Male, posterior ends. (Scale bar: A=200 $\mu \mathrm{m} ; B$ $=20 \mu \mathrm{m} ; C=40 \mu \mathrm{m} ; D-F=25 \mu \mathrm{m}$.) 
Paradolichodera tenuissima gen. $n$., $s p$. n. from New Zealand
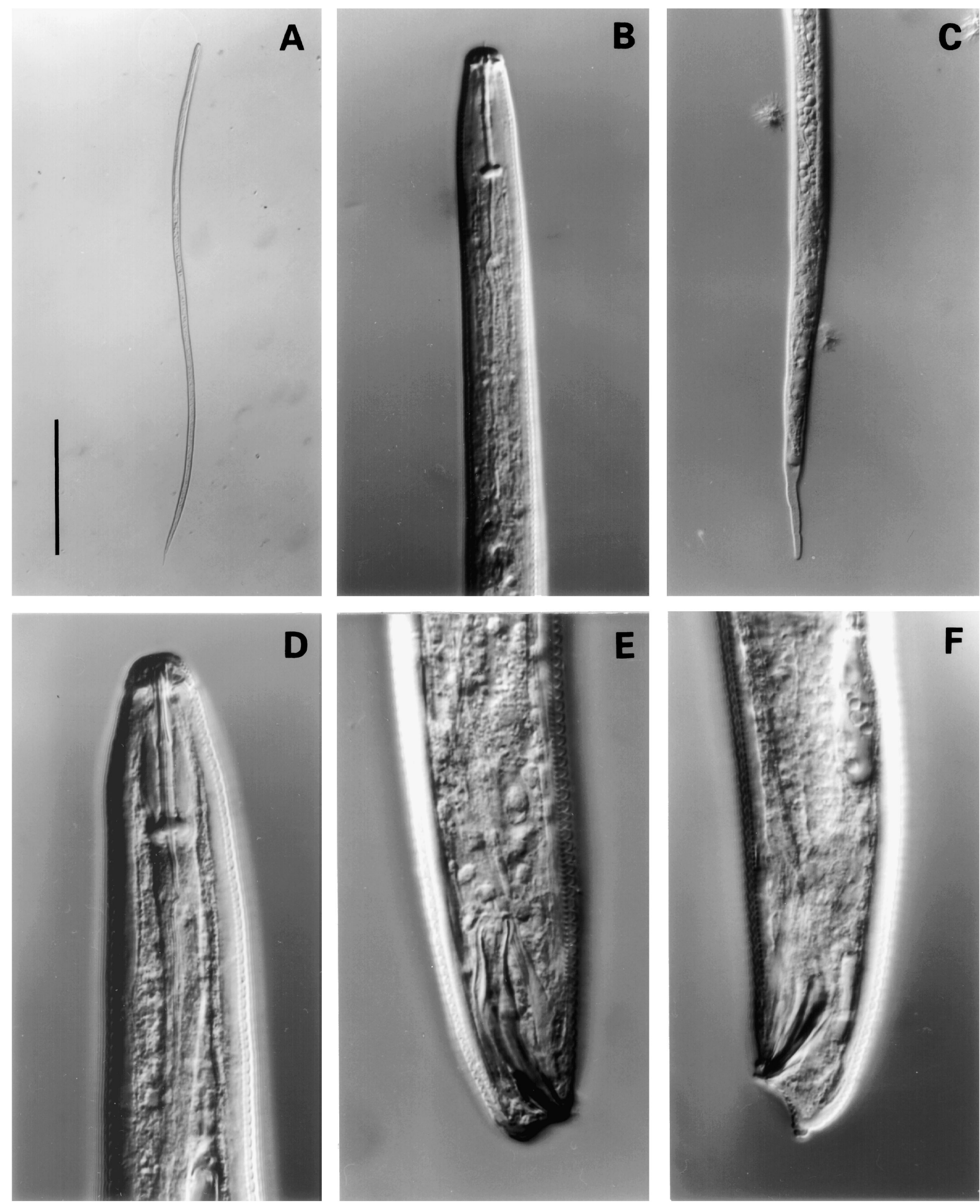

Vol. 9(4), 2007 

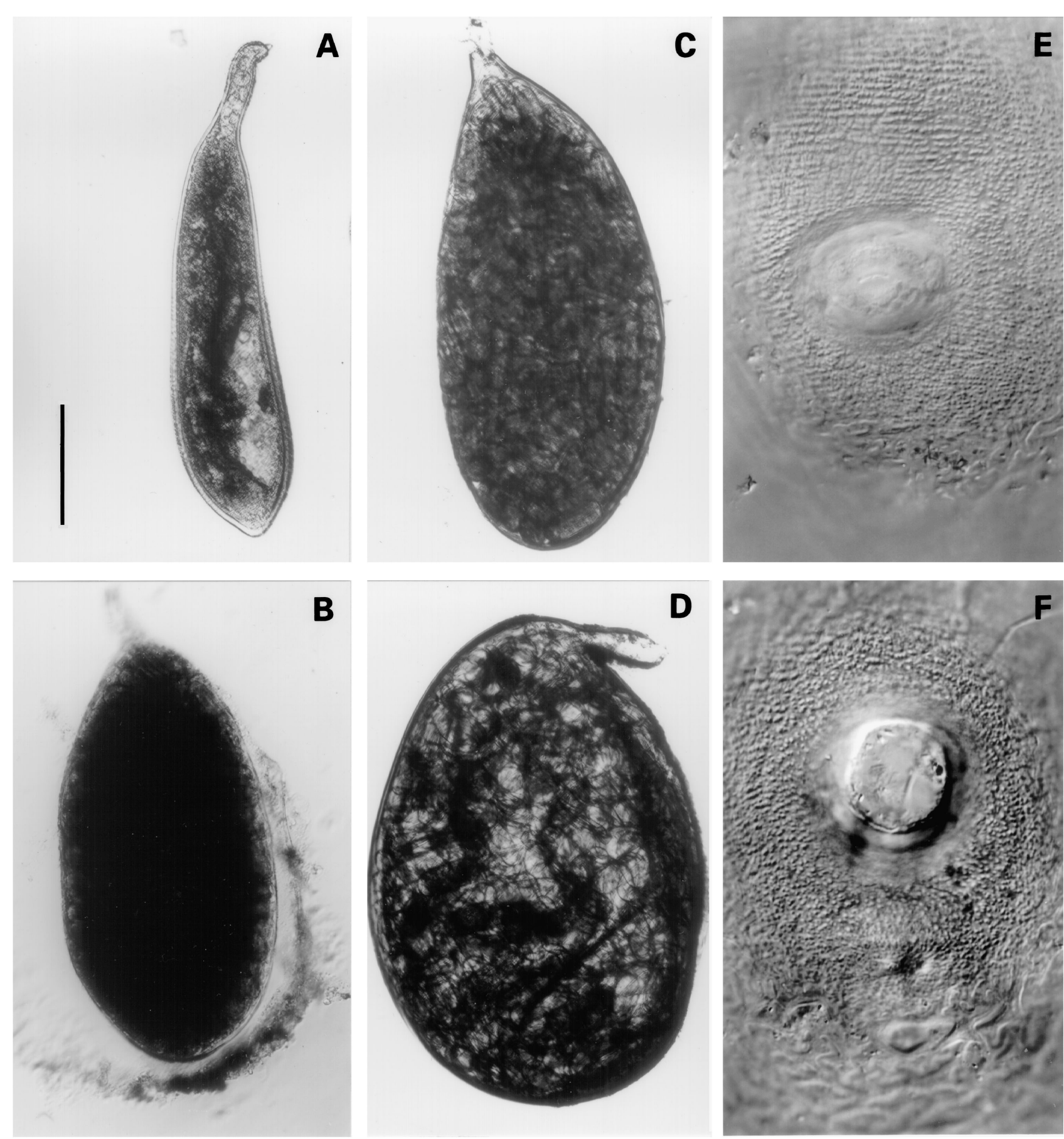

Fig. 3. Paradolichodera tenuissima gen. n., sp. n. LM micrographs. A: Young female; B: Female with dissolved 'subcrystalline' layer; C: Cyst filled with eggs (holotype); D: Older cyst containing egg shells and a few juveniles; E: Femalelyoung cyst posterior end showing vulval slit and developing circumfenestra; F: Cyst posterior end with vulval fenestra and anus (below). (Scale bar: A-D = 200 $\mu \mathrm{m}$; E, $F=20 \mu \mathrm{m}$.) 

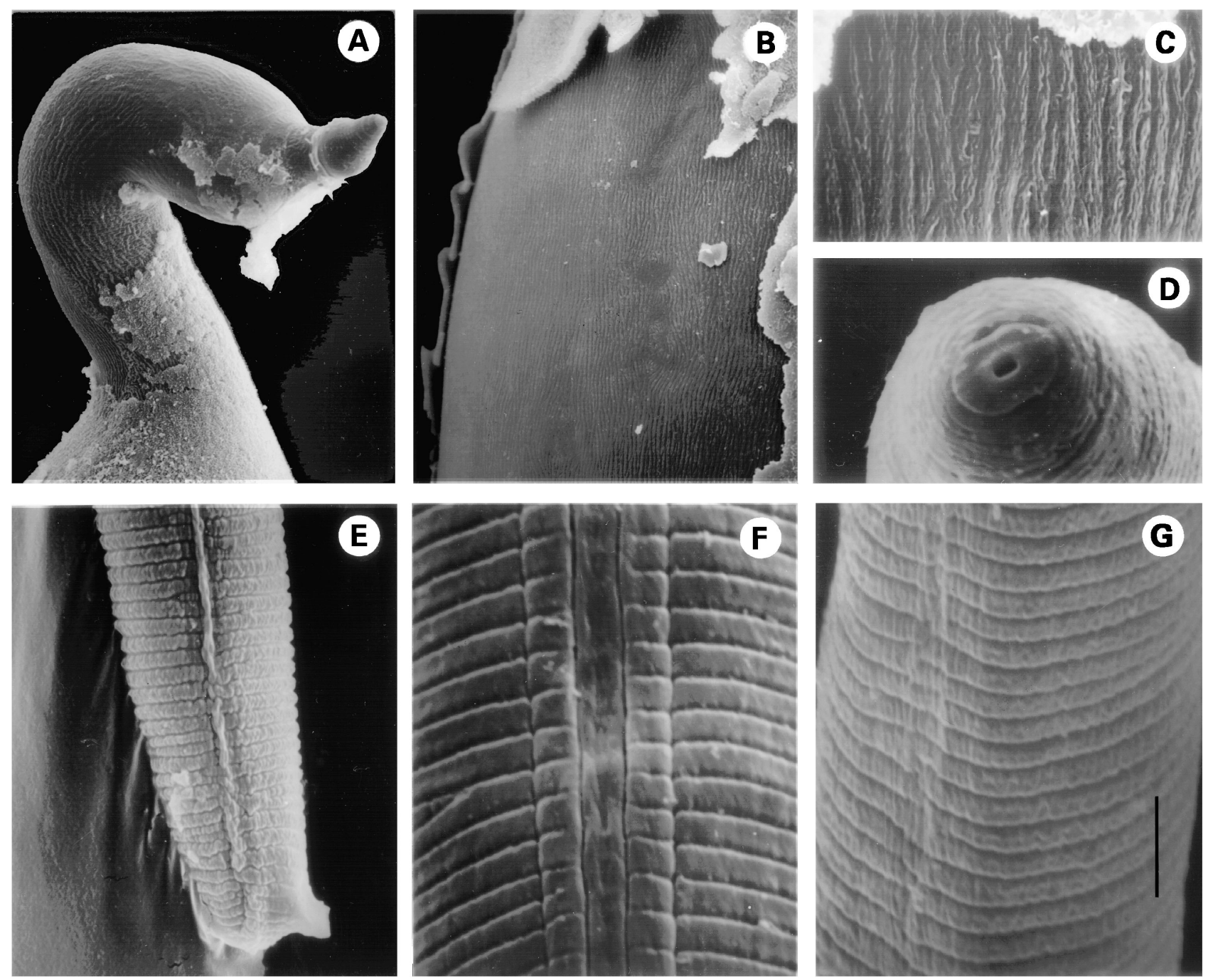

Fig. 4. Paradolichodera tenuissima gen. n., sp. n. SEM micrographs. A: Female neck region; B: Mature female, exposed cuticle with 'subcrystalline layer'; C: Detail of B, showing longitudinal stripes on cuticle; D: Male, face view; E: Male posterior end; F: Male, cuticle with lateral field in mid-body region; G: Second-stage juvenile cuticle with lateral field in mid-body region. (Scale bar: $A=25$ $\mu m ; B=20 \mu m ; C, D, F=5 \mu m ; E=15 \mu m ; G=3 \mu m$.)

diam. and 2-3 $\mu \mathrm{m}$ high, with few indistinct annules; labial disc elongate. Cephalic framework with strong central sclerotisation and rounded at base. Stylet slender, three lip region diam. long, conus and posterior stylet part of equal length, knobs well separated, rounded, with anterior faces flat or slightly sloping posteriorly. Stylet base 3.4-3.7 $\mu \mathrm{m}$ wide and 1.5-1.7 $\mu \mathrm{m}$ high. Dorsal gland orifice $c a$ twothirds of stylet length posterior to stylet base. Cephalids indistinct. Median pharyngeal bulb elongate, filling body cavity, somewhat angular with well developed $4 \mu \mathrm{m}$ long valves. Excretory-secretory pore $c a$ three corresponding body diam. posterior to level of centre of median bulb. Hemizonid just anterior to excretory-secretory pore, two cuticle annules long. Deirids absent. Pharyngeal glands long (40-46\% of body length), filling body cavity, broadly rounded at posterior end; dorsal gland generally well separated from subventral glands. Genital primordium with 2-6 (mostly four) cells, 12-16 $\mu \mathrm{m}$ long and 5-7 $\mu \mathrm{m}$ diam., $62-70 \%$ of body length from anterior end. Tail long and very slender; hyaline posterior portion of tail often not demarcated and containing granular inclusions; terminus 
D. Sturhan et al.

Table 1. Morphometrics of Paradolichodera tenuissima gen. n., sp. n. cysts, white females and eggs. All measurements are in $\mu m$ and in the form: mean \pm standard error (range).

\begin{tabular}{lccccc}
\hline Character & \multicolumn{2}{c}{ Cysts } & & Females & Eggs \\
\cline { 2 - 3 } & Holotype & Paratypes & & Paratypes & \\
\hline $\mathrm{n}$ & - & 25 & 10 & 25 \\
L (with neck) & 930 & $860 \pm 87(620-970)$ & & $780 \pm 51(660-880)$ & - \\
L (excluding neck) & 750 & $750 \pm 95(470-900)$ & & - & - \\
Length & - & - & - & $108 \pm 4.2(98-117)$ \\
Diam. & 360 & $335 \pm 63(205-505)$ & & $262 \pm 55(170-340)$ & $38 \pm 1.6(35-41)$ \\
Length (excl. neck)/diam. & 2.1 & $2.25 \pm 0.26(1.7-2.7)$ & & $3.1 \pm 0.6(2.4-4.6)$ & $2.86 \pm 0.2(2.5-3.3)$ \\
Stylet length & - & - & & $24.3 \pm 0.9(22.5-25)$ & - \\
\hline
\end{tabular}

Table 2. Morphometrics of paratype Paradolichodera tenuissima gen. $n$., sp. n. males and second-stage juveniles. All measurements are in $\mu \mathrm{m}$ and in the form: mean \pm standard error (range).

\begin{tabular}{lcc}
\hline Character & Males & Second-stage juveniles \\
\hline $\mathrm{n}$ & 10 & 25 \\
$\mathrm{~L}$ & $1370 \pm 74(1220-1455)$ & $825 \pm 32(750-880)$ \\
$\mathrm{a}$ & $41.7 \pm 2.3(38-45)$ & $71 \pm 4(61-79)$ \\
$\mathrm{b}$ & $9.0 \pm 0.3(8.5-9.6)$ & $6.9 \pm 0.7(5.8-8.0)$ \\
$\mathrm{b}^{\prime}$ & $4.55 \pm 0.3(4.1-5.1)$ & $2.3 \pm 0.1(2.1-2.5)$ \\
$\mathrm{c}$ & - & $10.2 \pm 0.5(9.1-11.1)$ \\
$\mathrm{c}^{\prime}$ & - & $9.6 \pm 0.6(8.0-10.6)$ \\
Stylet length & $25.6 \pm 0.6(25-26.5)$ & $18.5 \pm 0.5(17.5-19.5)$ \\
Opening of dorsal pharyngeal gland from stylet base & $10.4 \pm 0.8(9.0-12.0)$ & $12.9 \pm 1.0(11-15)$ \\
End of pharyngeal glands from anterior end & $300 \pm 21(270-340)$ & $362 \pm 13(330-385)$ \\
Cardia from anterior end & $152 \pm 9(131-166)$ & $120 \pm 14(98-143)$ \\
Median bulb from anterior end & $99 \pm 4(92-105)$ & $79 \pm 3(70-84)$ \\
Excretory pore from anterior end & $170 \pm 9(150-185)$ & $115 \pm 5(102-127)$ \\
Distance of genital primordium from anterior end (as $\%$ of body length) & - & $65 \pm 2(61-70)$ \\
Diam. at mid-body & $32.9 \pm 0.7(32-34)$ & $11.6 \pm 0.6(9.6-12.8)$ \\
Diam. at anus & - & $8.5 \pm 0.5(8.0-9.6)$ \\
Diam. at beginning of hyaline tail portion (HBD) & - & $3.2 \pm 0.5(2.4-4.0)$ \\
Genital tract length & - & -
\end{tabular}

finely rounded to pointed. Phasmids punctiform, one-third to half tail length posterior to anus.

Egg

Elongate, uniformly rounded at both ends, with smooth surface; egg shell $\mathrm{ca} 1.4 \mu \mathrm{m}$ thick, appearing doublelayered. Body of developed juveniles in embryonated eggs folded $c a$ seven times.

\section{TYPE HABITAT AND LOCALITY}

Isolated from moist loamy-sand samples with a high proportion of gravel from the rhizosphere of the rush Eleocharis gracilis $\mathrm{R}$. Br. (Cyperaceae) growing at the edge of a small lagoon behind the coastal gravel wall. Rakaia Huts, Selwyn, Canterbury, New Zealand (43 $53^{\prime} \mathrm{S}$, $\left.172^{\circ} 15^{\prime} \mathrm{E}\right)$. Not found in rhizosphere soil from Juncus 
spp., Poaceae and various dicotyledonous plants sampled in the type locality.

\section{TYPE MATERIAL}

Holotype (cyst), paratype cysts, females, males, second-stage juveniles and eggs deposited in the National Nematode Collection of New Zealand, Landcare Research, Auckland; additional paratypes (cysts, females, males, second-stage juveniles) in the German Nematode Collection, Biologische Bundesanstalt, Münster, Germany; and in nematode collections of Rothamsted Research, Harpenden, UK, and the University of California, Riverside, CA, USA.

\section{DIAGNOSIS AND RELATIONSHIPS}

Paradolichodera tenuissima gen. n., sp. n. is characterised by the characters of the genus, and most distinctly by the extremely slender second-stage juveniles. Cysts are elongate-ovoid with rounded posterior end, the cuticle is only light brown and translucent with heavy punctation and faint striation in the anterior part; the vulva region is circumfenestrate and the anus lacks fenestration; bullae are lacking.

On the basis of these features it is easily distinguished from all other described Heteroderidae species.

\section{PHYLOGENETIC RELATIONSHIPS USING MOLECULAR DATA}

Phylogenetic relationships of $P$. tenuissima gen. n., sp. n. with other species of the subfamily Punctoderinae inferred from maximum parsimony analysis of the ITS1rRNA gene sequences are given in Figure 5. Paradolichodera tenuissima gen. n., sp. n. forms a moderately supported clade (BS $=88 \%$ ) with Globodera and Punctodera and relationships between the three genera are not resolved. An analysis of the D2-D3 expansion segments of the 28S-rRNA gene sequence produced a similar result. In Bayesian consensus trees Paradolichodera gen. n. had a sister relationship with Punctodera, but with low or moderate posterior probability values (Subbotin et al., 2006).

\section{REMARKS}

In the systematics of the family Heteroderidae the transformation of the female after death into a cyst is considered a key character (Luc et al., 1986, 1988). Luc et al. (1986) defined a cyst as "a persistent tanned sac which retains eggs". In P. tenuissima gen. n., sp. n. the females often do not, or only slightly, change colour after death, the cuticle remaining transparent and their body generally filled with hatched juveniles or just egg shells. There is no evidence that eggs are laid or that there is a diapause in hatching. In $D$. fluvialis the cuticle also remains thin and transparent and eggs are retained in the dead female body. In both species mature females and 'cysts' are finely striated, at least in part of their body, and they lack a lace-like or reticulate surface pattern. In these characters Paradolichodera gen. n. and Dolichodera are intermediate between 'true' cyst-forming taxa and noncyst-forming Heteroderidae genera, in some of which the eggs are also retained within the dead females and the cuticle is annulated.

For heteroderids living in wet habitats, such as both P. tenuissima gen. n., sp. n. and D. fluvialis, there appears to be no 'necessity' to develop a 'persistent tanned sac' to protect eggs and juveniles. Also, for instance, in certain Heterodera species that are disposed to live in wet soils (such as $H$. bifenestra Cooper, 1955) the cysts are only slightly tanned and generally remain transparent. The extremely slender body of the $P$. tenuissima gen. n., sp. n. second-stage juveniles may also be an adaptation to the environment or the host roots. In some other Heteroderidae species specialised to Cyperaceae and Juncaceae the second-stage juveniles are also very slender and have a long tail, e.g., in Heterodera canadensis Mulvey, 1979 from Eleocharis acicularis (L.), Ekphymatodera thomasoni Baldwin, Bernard \& Mundo-Ocampo, 1989 from Juncus effusus L. and Verutus californicus Baldwin, Bernard \& Mundo-Ocampo, 1989 from Carex sp.; similarly also in certain Meloidogyne species (e.g., M. sewelli Mulvey \& Anderson, 1980 from E. acicularis). Dolichodera fluvialis, which was described from an aquatic habitat with the grass Spartina pectinata Link being the putative host (Ebsary, 1986), also has second-stage juveniles that are long and slender $(\mathrm{a}=27$ $31)$ and possess a long tail (95-120 $\mu \mathrm{m})$.

Among all species in the subfamily Punctoderinae, $P$. tenuissima gen. n., sp. n. very closely resembles $D$. fluvialis, the type and only species of the genus Dolichodera. Both species lack fenestration around the anus of the cyst and both have juveniles with indistinct lateral lines. The two species are also similar in other morphological details of the cysts. It was, therefore, difficult to decide if their individual morphological peculiarities should be accepted as mere adaptations to their particular environments and place them both in the poorly defined genus Dolichodera, 


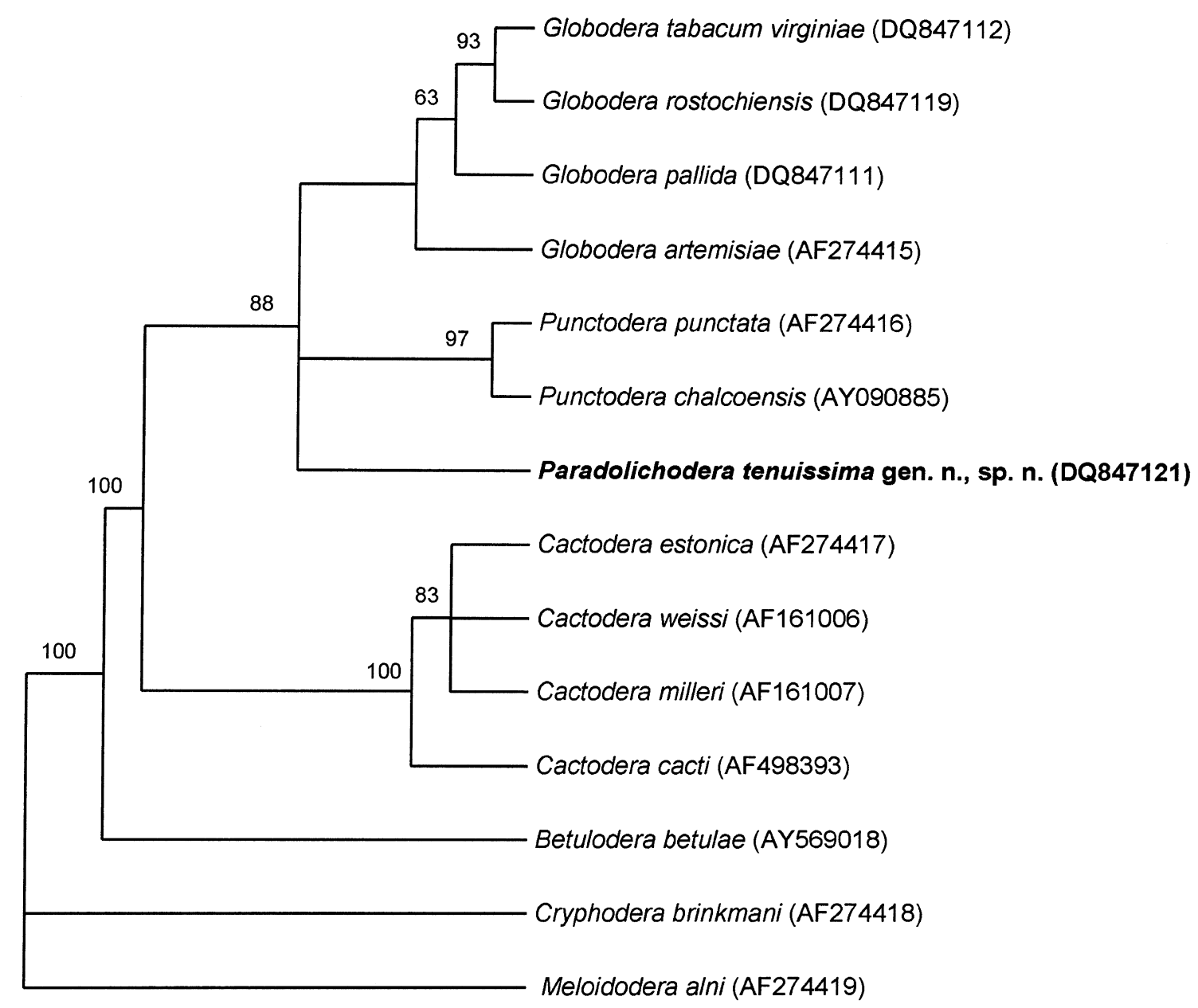

Fig. 5. Phylogenetic relationships of Paradolichodera tenuissima gen. $n$., sp. $n$. with other representatives of the subfamily Punctoderinae as inferred from maximum parsimony analysis of the ITS1-rRNA sequences. (Strict consensus of three maximum parsimonious trees; number of parsimony informative characters $=236$; tree length $=778 ; C I=0.7571 ; H I=0.2429$.) Bootstrap values greater than $50 \%$ are given for appropriate clades.

or to accept them as separate genera. Though $P$. tenuissima gen. n., sp. n. is very similar to Dolichodera, its unique, slender, atypical heteroderid juvenile was considered sufficient justification to recognise the species to represent an independent genus. Further comparative molecular and morphological studies of $D$. fluvialis material, when it becomes available, and especially its elusive male, may further clarify the taxonomic position of the two taxa.

\section{Acknowledgements}

We thank Karen Knight, formerly Ministry of Agriculture and Forestry, National Plant Pest Reference Lab- oratory, Lincoln, for collecting several soil samples at the type locality, and Birgit E. Rhode, Landcare Research, Auckland, New Zealand, for preparing the SEM microphotographs. The first author visited New Zealand within the German-New Zealand cooperation programme in agricultural research, cooperation project 94.06. Sergei A. Subbotin acknowledges support from the USDA grant 2005-00903.

\section{References}

Baldwin, J.G., Bernard, E.C. \& Mundo-Ocampo, M. (1989). Four new species of Heteroderidae including Ekphy- 
matodera $\mathrm{n}$. gen. from California. Journal of Nematology 21, 48-68.

EBSARY, B.A. (1986). Species and distribution of Heteroderidae and Meloidogynidae (Nematoda: Tylenchida) in Canada. Canadian Journal of Plant Pathology 8, 170-184.

Ferris, V.R., Krall, E., Faghihi, J. \& Ferris, J.M. (1999). Phylogenetic relationships of Globodera millefolii, Globodera artemisiae, and Cactodera salina based on ITS regions of ribosomal DNA. Journal of Nematology 31, 498507.

FERris, V.R., SABo, A., BALDWIN, J.G., MUNdo-OCAMPo, M., Inserra, R.N. \& Sharma, S. (2004). Phylogenetic relationships among selected Heteroderoidea based on $18 \mathrm{~S}$ and ITS ribosomal DNA. Journal of Nematology 36, 202-206.

Luc, M., Weischer, B., Stone, A.R. \& BAldwin, J.G. (1986). On the definition of heteroderid cysts. Revue de Nématologie 9, 418-421.

Luc, M., Maggenti, A.R. \& Fortuner, R. (1988). A reappraisal of Tylenchina (Nemata). 9. The family Heteroderidae Filip'jev \& Schuurmans Stekhoven, 1941. Revue de Nématologie 11, 159-176.

Mulvey, R.H. \& EBSARY, B.A. (1980). Dolichodera fluvialis n. gen., n. sp. (Nematoda: Heteroderidae) from Québec, Canada. Canadian Journal of Zoology 58, 1697-1702.

Sabo, A., Reis, L., Krall, E., Mundo-Ocampo, M. \& FERRIS, V.R. (2002). Phylogenetic relationships of a distinct species of Globodera from Portugal and two Punctodera species. Journal of Nematology 34, 263-266.

Subbotin, S.A., Halford, P.D., Warry, A. \& Perry, R.N. (2000). Variations in ribosomal DNA sequences and phylogeny of Globodera parasitising Solanaceae. Nematology 2, 591-604.
Subbotin, S.A., Vierstraete, A., De Ley, P., Rowe, J., Waeyenberge, L., Moens, M. \& Vanfleteren, J.R. (2001). Phylogenetic relationships within the cyst-forming nematodes (Nematoda, Heteroderidae) based on analysis of sequences from the ITS regions of ribosomal DNA. Molecular Phylogenetics and Evolution 21, 1-16.

Subbotin, S.A., Sturhan, D. \& Moens, M. (2002). Molecular phylogenetics of the cyst-forming nematodes (Tylenchida: Heteroderidae). Nematology 4, 181-182. [Abstr.]

Subbotin, S.A., Sturhan, D., Chizhov, V.N., Vovlas, N. \& BALDWIN, J.G. (2006). Phylogenetic analysis of Tylenchida Thorne, 1949 as inferred from D2 and D3 expansion fragments of the 28S rRNA gene sequences. Nematology 8 , 455-474.

SWOFFORD, D.L. (2003). PAUP*: Phylogenetic analysis using parsimony (*and other methods), version $4.0 \mathrm{~b} 10$. Sunderland, MA, USA, Sinauer Associates.

Tanha Maafi, Z., Subbotin, S.A. \& Moens, M. (2003). Molecular identification of cyst-forming nematodes (Heteroderidae) from Iran and a phylogeny based on ITS-rDNA sequences. Nematology 5, 99-111.

Thompson, J.D., Gibson, T.J., Plewniak, F., JeanmouGIN, F. \& Higgins, D.G. (1997). The ClustalX Windows interface: flexible strategies for multiple sequence alignment aided by quality analysis tools. Nucleic Acids Research 24, 4876-4882.

Zheng, J., Subbotin, S.A., Waeyenberge, L. \& Moens, M. (2000). Molecular characterisation of Chinese Heterodera glycines and $H$. avenae populations based on RFLPs and sequences of rDNA-ITS regions. Russian Journal of Nematology 8, 109-113. 